\title{
Penerapan Model Pembelajaran Inkuiri Terbimbing Untuk Meningkatkan Keterampilan Proses Sains dan Hasil Belajar Peserta Didik
}

\author{
Yeni Sariani Hasan ${ }^{1)}$, Erniwati $^{2)}$, Luh Sukariasih ${ }^{3)}$ \\ 1)*Mahasiswa Jurusan Pendidikan Fisika, FKIP, Universitas Halu Oleo, Kendari, Sulawesi Tenggara \\ ${ }^{2), 3)}$ Dosen Jurusan Pendidikan Fisika, FKIP, Universitas Halu Oleo, Kendari, Sulawesi Tenggara \\ *Korespondensi Email: yenisarianihasan@gmail.com
}

\begin{abstract}
Abstrak: Penelitian ini bertujuan untuk meningkatkan proses keterampilan sains peserta didik pada materi pokok usaha dan pesawat sederhana dengan menggunakan model pemeblajaran inkuiri terbimbing. Teknik pengumpulan data dalam penelitian ini adalah dilakukan dengan pemberian instrumen penelitian yaitu tes keterampilan proses sains berupa tes uraian dan tes hasil belajar IPA berupa tes pilihan ganda. Data penelitian dianalisis dengan menggunakan dua teknik analisis statistik yaitu analisis statistik deskriptif dan analisis statistik inferensial. Hasil penelitian menunjukkan bahwa penerapan model pembelajaran inkuiri terbimbing dapat meningkatkan keterampilan proses sains dan hasil belajar IPA peserta didik kelas VIII SMP Negeri 2 Binongko pada materi pokok Usaha dan Pesawat Sederhana dengan tingkat kepercayaan $95 \%$.
\end{abstract}

Kata Kunci: Keterampilan Proses Sains, Hasil Belajar IPA, Model pembelajaran Inkuiri Terbimbing, Pendekatan Saintifik.

\begin{abstract}
This study aims to improve the process of students' science skills on the subject matter of business and simple aircraft by using a guided inquiry learning model. The data collection technique in this study was carried out by providing research instruments, namely a science process skills test in the form of a description test and a science learning outcome test in the form of a multiple choice test. The research data were analyzed using two statistical analysis techniques, namely descriptive statistical analysis and inferential statistical analysis. The results showed that the application of the guided inquiry learning model could improve science process skills and science learning outcomes of class VIII students of SMP Negeri 2 Binongko on the subject matter of Business and Simple Aircraft with a $95 \%$ confidence level.
\end{abstract}

Keywords: Science Process Skills, Science Learning Outcomes, Guided Inquiry Learning Model, Scientific Approach.

\section{PENDAHULUAN}

Ilmu Pengetahuan Alam (IPA) merupakan salah satu mata pelajaran di tingkat SMP/MTs yang berkaitan dengan cara mencari tahu tentang alam secara sistematis, sehingga IPA bukan hanya penguasaan kumpulan pengetahuan yang berupa fakta-fakta, konsep-konsep, atau prinsip-prinsip saja tetapi juga merupakan suatu proses penemuan. Hal inilah yang disebut IPA sebagai produk dan IPA sebagai proses. IPA sebagai produk meliputi kumpulan pengetahuan yang terdiri dari fakta, konsep dan prinsip. IPA sebagai proses meliputi keterampilan dan sikap yang dimiliki ilmuwan dalam bekerja secara ilmiah. Aspek proses tersebut salah satunya adalah keterampilan proses sains. Fakta dilapangan menunjukkan bahwa pembelajaran IPA saat ini umumnya lebih terorientasi pada aspek produk sains dan kurang mengembangkan proses sains. Pembelajaran yang terorientasi pada produk cenderung bersifat teoritis dan berpusat pada guru, dimana guru menjadi sumber pengetahuan, sehingga peserta didik bersifat pasif dalam proses pembelajaran.

Model pembelajaran inkuiri terbimbing merupakan sebuah model pembelajaran yang bersifat student centered atau berpusat pada peserta didik, model pembelajaran ini menempatkan peserta didik dalam situasi dimana peserta didik dituntut 
untuk bereksperimen secara mandiri agar dapat melihat sendiri fenomena yang terjadi (Evriani, 2017). Model pembelajaran inkuiri terbimbing sangat sesuai untuk mengembangkan keterampilan proses sains, karena sintaks atau tahap pembelajaran di dalam inkuiri terbimbing yang dikembangkan dengan metode ilmiah dapat melatihkan keterampilan proses sains pada peserta didik (Wulanningsih, 2012). Model pembelajaran inkuiri terbimbing dapat meningkatkan hasil belajar aspek kognitif. Hal ini dikarenakan model pembelajaran inkuiri terbimbing peserta didik dibimbing untuk menemukan konsep dari pengamatan sehingga peserta didik lebih mudah mengabstraksikan ke dalam pikiran (Muliyani, 2016).

Berdasarkan hasil penelitian Rahmazani (2017) menyatakan bahwa adanya peningkatan keterampilan proses sains dan hasil belajar peserta didik setelah penerapan model inkuri terbimbing. Selain itu, hal ini juga dibuktikan oleh Iswatun (2017) menyatakan bahwa Model pembelajaran inkuiri terbimbing dapat meningkatkan keterampilan proses sains dan hasil belajar peserta didik.

\section{METODE}

Penelitian ini termasuk jenis penelitian eksperimen. Penelitian ini dilaksanakan pada semester ganjil, tahun ajaran 2018/2019 di SMP Negeri 2 Binongko. Populasi dalam penelitian ini adalah seluruh peserta didik kelas VIII SMP Negeri 2 Binongko yang terdaftar pada semester ganjil tahun ajaran 2018/2019 yang terdistribusi dari 3 kelas dengan jumlah peserta didik sebanyak 52 orang. Penentuan sampel pada penelitian ini digunakan teknik Simple Random Sampling. Namun sebelum dilakukan teknik pengambilan sampel tersebut terlebih dahulu diuji homogen dengan uji Levene Statistic menggunakan bantuan SPSS.

Penelitian ini menggunakan desain Randomized Control Groups Post tes- Pre test. Desain ini merupakan desain sederhana yang mendapatkan satu perlakuan dan sebuah kontrol. Selengkapnya dapat disajikan sebagai berikut (Sugiyono, 2017). Variabel dalam penelitian ini terdiri atas dua variabel, yaitu variabel bebas dan variabel terikat. Variabel bebas dalam penelitian adalah kelas yang diajar dengan model pembelajaran inkuiri terbimbing. Sedangkan variabel terikatnya adalah keterampilan proses sains dan hasil belajar IPA peserta didik pada materi pokok usaha dan pesawat sederhana.

Teknik pengumpulan data dalam penelitian ini adalah dilakukan dengan pemberian instrumen penelitian yaitu data keterampilan proses sains berupa tes uraian dan tes hasil belajar IPA berupa tes pilihan ganda yang diberikan kepada peserta didik. Tes ini dilakukan sebanyak dua kali yaitu sebelum kelas diberikan perlakuan dan setelah kelas diberikan perlakuan.

Penelitian eksperimen untuk keterampilan proses sains dan hasil belajar IPA menggunakan dua teknik analisis statistik yaitu analisis statisitik deskriptif sebagaimana yang diuraikan di dalam Sugiyono (2017) dan Arikunto (2008) dan analisis statistik inferensial sebagaimana yang diuraikan didalam Sudjana (2002)

\section{HASIL PENELITIAN \\ Analisis Deskriptif}

Data tes awal dan tes akhir keterampilan proses sains peserta didik kelas eksperimen dan kelas kontrol dapat dilihat pada Gambar 1.

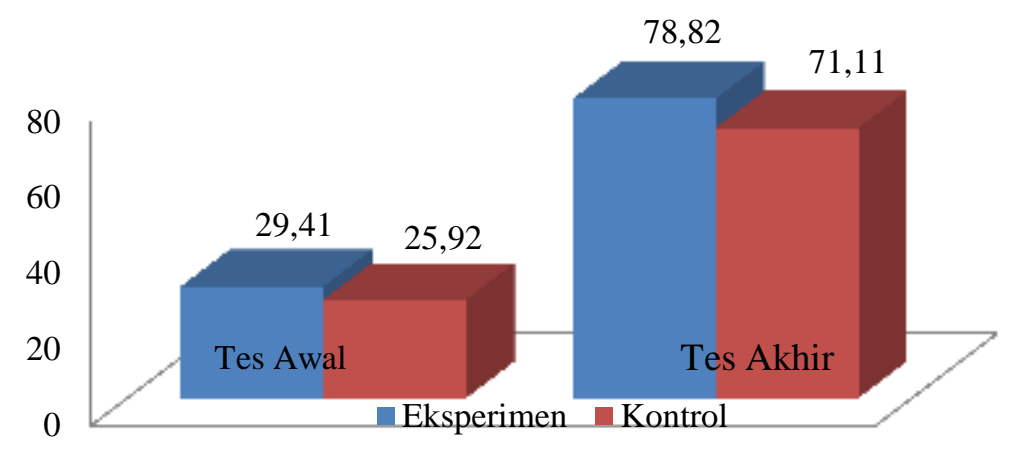

Gambar 1 Grafik Tes Awal dan Tes Akhir Keterampilan Proses Sains Peserta Didik Kelas Eksperimen dan Kelas Kontrol 
Data tes awal dan tes akhir hasil belajar IPA peserta didik kelas eksperimen dan kelas kontrol dapat dilihat pada Gambar 2 berikut:

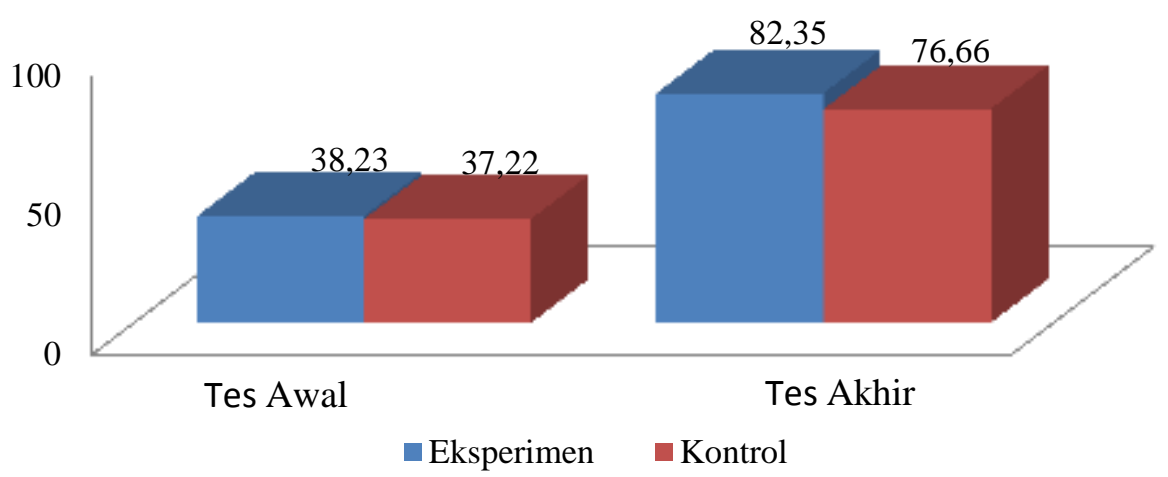

Gambar 2. Grafik Tes Awal dan Tes Akhir Hasil Belajar IPA Peserta Didik Kelas Eksperimen dan Kelas Kontrol

\section{Analisis Inferensial}

a) Uji Normalitas data

Uji normalitas digunakan untuk mengetahui apakah keterampilan proses sains dan hasil belajar IPA peserta didik kedua kelas berdistribusi normal atau digunakan statistik uji normalitas dengan rumus
Kolmogorov-Smirnov dimana hasil perhitungannya adalah nilai Asymp. Sig. (2-tailed) untuk kelas eksperimen dan kelas kontrol lebih besar dari $\alpha=$ 0,05 sehingga $\mathrm{H}_{0}$ diterima dapat dilihat pada Tabel 1.

Tabel 1. Hasil Uji Normalitas Data Keterampilan Poses Sains dan Hasil Belajar IPA Peserta Didik pada Materi Usaha dan Pesawat Sederhana Peserta Didik Kelas Eksperimen dan Kelas Kontrol

\begin{tabular}{|c|c|c|c|c|c|c|c|c|}
\hline \multirow{3}{*}{ Kelas } & \multirow{3}{*}{$\begin{array}{c}\text { Bentuk } \\
\text { Tes }\end{array}$} & \multicolumn{5}{|c|}{ Kolmogorov-Smirnov ${ }^{a}$} & \multirow{3}{*}{$\alpha$} & \multirow{3}{*}{ Kesimpulan } \\
\hline & & \multicolumn{2}{|c|}{ KPS } & \multicolumn{2}{|c|}{ HBI } & \multirow[t]{2}{*}{ df } & & \\
\hline & & Statistic & Sig. & Statistic & Sig. & & & \\
\hline \multirow[t]{2}{*}{ Eksperimen } & Tes Awal & 0,18 & 0,14 & 0,17 & 0,15 & 17 & \multirow{4}{*}{$\begin{array}{c}0,0 \\
5\end{array}$} & \multirow{4}{*}{$\begin{array}{c}\text { Data } \\
\text { Terdistribusi } \\
\text { Normal }\end{array}$} \\
\hline & Tes Akhir & 0,20 & 0,06 & 0,17 & 0,18 & 17 & & \\
\hline \multirow[t]{2}{*}{ Kontrol } & Tes Awal & 0,20 & 0,06 & 0,14 & 0,20 & 18 & & \\
\hline & Tes Akhir & 0,18 & 0.14 & 0,20 & 0.06 & 18 & & \\
\hline
\end{tabular}

KPS : Keterampilan Proses Sains

*HBI : Hasil Belajar IPA

b) Uji Homogenitas Varians Data

Hasil uji homogenitas varians data adalah nilai Asymp. Sig. (2-tailed) lebih besar dari a keterampilan proses sains dan hasil belajar IPA Tabel 2. peserta didik kelas eksperimen dan kelas kontrol

Tabel 2. Hasil Uji Homogenitas Varians Data Tes Awal dan Tes Akhir Peserta Didik Kelas Eksperimen dan Kelas Kontrol

\begin{tabular}{|c|c|c|c|c|c|c|c|}
\hline $\begin{array}{l}\text { Dat } \\
\text { a }\end{array}$ & Tes & $\begin{array}{l}\text { Levene } \\
\text { statistic }\end{array}$ & $\mathbf{d f}_{1}$ & $\mathbf{d f}_{2}$ & Sig. & $\alpha$ & Kesimpulan \\
\hline \multirow[t]{2}{*}{ KPS } & Tes Awal & 0,254 & 1 & 33 & 0,618 & \multirow{4}{*}{0,05} & \multirow{4}{*}{ Data Homoger } \\
\hline & Tes Akhir & 0,398 & 1 & 33 & 0,513 & & \\
\hline \multirow[t]{2}{*}{ HBI } & Tes Awal & 0,385 & 1 & 33 & 0,539 & & \\
\hline & Tes Akhir & 0,003 & 1 & 33 & 0,960 & & \\
\hline
\end{tabular}


*KPS : Keterampilan Proses Sains

"HBI : Hasil Belajar IPA

c) Pengujian Hipoteis

Hasil uji N-Gain keterampilan proses sains peserta didik kelas eksperimen dan kelas kontrol adalah nilai Sig. (2-tailed) lebih kecil dari $\alpha=0,05$, maka $\mathrm{H}_{1}$ diterima yang berarti nilai rata-rata $\mathrm{N}$-Gain keterampilan proses sains peserta didik kelas eksperimen lebih tinggi daripada nilai rata-rata $\mathrm{N}$ Gain keterampilan proses sains peserta didik kelas kontrol dapat dilihat pada Tabel 3 berikut:

Tabel 3 Hasil Uji N-Gain Keterampilan Proses Sains Peserta Didik Kelas Eksperimen dan Kelas Kontrol

\begin{tabular}{cccccccl}
\hline Kelas & N & Rata-Rata & $\begin{array}{c}\text { Std. } \\
\text { Deviasi }\end{array}$ & df & $\begin{array}{c}\text { Sig. (2- } \\
\text { tailed) }\end{array}$ & $\boldsymbol{\alpha}$ & Kesimpulan \\
\hline Eksperimen & 17 & 0,700 & 0,091 & 33 & 0,009 & 0,05 & $\mathrm{H}_{0}$ Ditolak \\
\hline Kontrol & 18 & 0,607 & 0,105 & & & \\
\hline
\end{tabular}

Hasil uji N-Gain hasil belajar IPA peserta didik kelas eksperimen dan kelas kontrol adalah nilai Sig. (2-tailed) lebih kecil dari $\alpha=0,05$ maka $\mathrm{H}_{1}$ diterima yang berarti nilai rata-rata N-Gain hasil belajar IPA

Tabel 4. Hasil Uji N-Gain Hasil Belajar IPA Peserta Didik Kelas Eksperimen dan Kelas Kontrol

\begin{tabular}{cccccccc}
\hline Kelas & N & Rata-Rata & $\begin{array}{c}\text { Std. } \\
\text { Deviasi }\end{array}$ & df & $\begin{array}{c}\text { Sig. (2- } \\
\text { tailed) }\end{array}$ & $\boldsymbol{\alpha}$ & Kesimpulan \\
\hline Eksperimen & 17 & 0,717 & 0,102 & 33 & 0,012 & 0,05 & $\mathrm{H}_{0}$ Ditolak \\
\hline Kontrol & 18 & 0,626 & 0,101 & & &
\end{tabular}

\section{PEMBAHASAN}

Nilai rata-rata tes akhir keterampilan proses sains setelah diterapkan model pembelajaran inkuiri terbimbing pada kelas eksperimen dan pendekatan saintifik pada kelas kontrol diperoleh nilai rata-rata tes akhir kelas eksperimen lebih besar dibandingkan kelas kontrol. Rata-rata tes akhir pada kelas eksperimen sebesar 78,82 sedangkan kelas kontrol sebesar 71,11. Hal ini menunjukkan bahwa terdapat perbedaan yang signifikan antara nilai rata-rata tes akhir keterampilan proses sains peserta didik kelas eksperimen dan kelas kontrol.

Hasil analisis uji nilai rata-rata N-Gain keterampilan proses sains kelas eksperimen diperoleh sebesar 0,70 termasuk kategori sedang sementara kelas kontrol sebesar 0,61 termasuk kategori sedang. Hal ini disebabkan karena keterampilan proses sains kelas eksperimen dan kelas kontrol diukur dengan menggunakan tes yang dilakukan pada akhir pembelajaran setelah diterapkan perlakuan pada masing-masing kelas dan tes yang digunakan untuk mengukur keterampilan proses sains merupakan tes yang berisi pertanyaanpertanyaan pada saat kegiatan pembelajaran berlangsung. Dimana pertanyaan-pertanyaan tersebut terdapat pada lembar kegiatan peserta didik pada saat melakukan praktikum, sehingga peserta didik diduga mengahafal petanyaan-pertanyaan tersesbut.

Langkah-langkah inkuiri terbimbing yang padat membuat peserta didik berperan aktif dalam proses pembelajaran di kelas. Hasil pengamatan dalam pembelajaran inkuiri terbimbing, peserta didik memiliki kesempatan yang luas untuk menumbuhkan dan meningkatkan keterampilan proses sains melalui kegiatan penyelidikan seperti yang dilakukan oleh seorang ilmuan. Hal ini didukung oleh Zehra dan Nermin (2009) menyatakan bahwa model inkuiri terbimbing mampu meningkatkan keterampilan proses peserta didik.

Nilai rata-rata tes akhir hasil belajar IPA setelah diterapkan model pembelajaran inkuiri terbimbing pada kelas eksperimen dan pendekatan saintifik pada kelas kontrol diperoleh nilai rata-rata tes akhir kelas eksperimen lebih besar dibandingkan kelas kontrol. Rata-rata tes akhir pada kelas eksperimen sebesar 82,35 sedangkan kelas kontrol sebesar 76,66. Hal ini menunjukkan bahwa terdapat perbedaan yang signifikan antara nilai rata-rata tes akhir hasil belajar IPA peserta didik kelas eksperimen dan kelas kontrol.

Hasil analisis uji nilai rata-rata N-Gain hasil belajar IPA kelas eksperimen diperoleh sebesar 0,72 termasuk kategori tinggi sementara kelas 
kontrol sebesar 0,63 termasuk kategori sedang. Hasil analisis tersebut menunjukkan bahwa nilai rata-rata N-Gain hasil belajar IPA kelas eksperimen lebih tinggi secara signifikan daripada nilai rata-rata N-Gain hasil belajar IPA kelas kontrol. Meningkatnya hasil belajar IPA kelas eksperimen disebabkan oleh keterlibatan peserta didik selama proses pembelajaran berlangsung. Model pembelajaran inkuiri terbimbing memusatkan pembelajaran pada peserta didik. Dimana guru menyampaikan materi dengan mengaitkan keseharian peserta didik, dan pengetahuan yang diperoleh lebih menyeluruh dan bermakna dalam suatu keterpaduan konsep materi sehingga peserta didik lebih cepat dan mudah memahami apa yang disampaikan oleh guru dibandingkan dengan kelas kontrol yang hanya memperoleh informasi dari guru dan pengetahuan yang masih terkotak-kotak. Selain itu juga pembelajaran inkuiri terbimbing pada kelas eksperimen peserta didik diarahkan bekerjasama dengan kelompok belajarnya, menumbuhkan minat peserta didik untuk menggali informasi yang belum mereka ketahui sebelumnya sehingga peserta didik mampu memotivasi diri sendiri karena rasa kengintahuan dalam diri mereka. Peserta didik menjadi lebih aktif dalam proses pembelajaran memperoleh pengetahuan melalui pengalaman langsung, bukan hanya sekedar mendengar dan menerima pengetahuan atau informasi apa yang dikatakan oleh guru (Wijayanti, 2013).

\section{.KESIMPULAN}

Berdasarkan rumusan masalah serta hasilhasil analisis data dan pengujian hipotesis dapat ditarik kesimpulan secara umum bahwa model pembelajaran inkuiri terbimbing dapat meningkatkan keterampilan proses sains dan hasil belajar IPA peserta didik kelas VIII pada materi pokok usaha dan pesawat sederhana SMP Negeri 2 Binongko dengan tingkat kepercayaan $95 \%$ atau peluang kekeliruan $5 \%$.

\section{DAFTAR PUSTAKA}

Arikunto, S. 2008. Penelitian Hasil Belajar Mengajar. Remaja Rosdakarya. Bandung.

Arikunto, S. 2013. Dasar-Dasar Evaluasi Pendidikan Edisi 2. Rineka Cipta. Jakarta.

Evriani, Yudi Kurniawan, dan Riska Muliyani. 2017. Peningkatan Keterampilan Proses Sains (KPS) Terpadu melalui Penerapan Model Pembelajaran

Iswatun, I, M. Mosik dan Bambang Subali. 2017. Penerapan Model Pembelajaran Inkuiri Terbimbing untuk Meningkatkan KPS dan Hasil Belajar Peserta Didik SMP Kelas VIII. Jurnal Inovasi Pendidikan IPA. Vol. 3. No. 2. hlm 150-160

Sugiyono, 2017. Metode Penelitian Pendidikan Pendekatan Kuantitatif,Kualitatif, Dan $R \&$ $D$. Alfabeta. Bandung.

Wijayanti, P. I, Mosik dan Hindarto, N. 2010. Eksplorasi Kesulitan Belajar Peserta Didik pada Pokok Bahasan Cahaya dan Upaya Peningkatan Hasil Belajar Melalui Pembelajaran Inkuiri Terbimbing. Jurnal Pendidikan Fisika Indonesia. hlm 1-5.

Wullanningsih, Sri, Baskoro dan Riezky. 2012. Pengaruh Model Pembelajaran Inkuiri Terbimbing terhadap Keterampilan Proses Sains Ditinjau dari Kemampuan Akademik Siswa SMA Negeri 5 Surakarta. Jurnal Pendidikan Biologi. Vol. 4 No. 2. hlm 3343. 